\title{
Koenigsmacker
}

Sablière de Sentzich, Mesch, phase 2

\section{Marie-Pierre Petitdidier}

\section{(2) OpenEdition}

Journals

Édition électronique

URL : http://journals.openedition.org/adlfi/8794

ISSN : 2114-0502

Éditeur

Ministère de la culture

Référence électronique

Marie-Pierre Petitdidier, «Koenigsmacker», ADLFI. Archéologie de la France - Informations [En ligne],

Lorraine, mis en ligne le 01 mars 2001, consulté le 20 avril 2019. URL : http://journals.openedition.org/ adlfi/8794

Ce document a été généré automatiquement le 20 avril 2019.

(C) Ministère de la Culture et de la Communication, CNRS 


\title{
Koenigsmacker
}

Sablière de Sentzich, Mesch, phase 2

\author{
Marie-Pierre Petitdidier
}

Identifiant de l'opération archéologique : F1357200100072

Date de l'opération : 2001 (EV)

1 À l'occasion de l'extension d'une sablière, au lieu-dit « Mesch ", portant sur une surface de 1,7 ha, le service régional de l'Archéologie de Lorraine a procédé à un diagnostic systématique préalable, qui n'a pas révélé la présence de vestige archéologique.

INDEX

Index géographique : Lorraine, Moselle (57), Kœnigsmacker (57370)

operation Fouille d'évaluation (EV)

\section{AUTEURS}

MARIE-PIERRE PETITDIDIER

AFAN 